\title{
Pengaruh Etos Kerja, Pelatihan Kerja, dan Disiplin Kerja Terhadap Kinerja Karyawan PT. Bumi Menara Internusa
}

\author{
Deni Syesilia ${ }^{1}$, Mochamad Syaiful Arif ${ }^{2}$ \\ Universitas Wijaya Putra Surabaya \\ denisyesilia@gmail.com ${ }^{1}$, msyariful.arif@uwp.ac.id ${ }^{2}$
}

\begin{abstract}
The main objective of this study is to test and analyze the influence of work ethic, job training and work discipline on employee performance at PT. Earth Tower Internusa. Data collection uses primary data obtained from questionnaires. The sample in this study was an employee of PT. Bumi Menara Internusa Surabaya which numbers 62 people. The analysis used in hypothesis testing is statistical package for the social sciences (SPSS) version 20. The results of this study showed that work ethic had no significant effect on employee performance, job training had a positive and insignificant effect on employee performance, and work discipline had no significant effect on employee performance.
\end{abstract}

Keywords: Work ethic, job training, work discipline and employee performance.

\begin{abstract}
Abstrak: Tujuan utama studi ini adalah untuk menguji dan menganalisis pengaruh etos kerja, pelatihan kerja dan disiplin kerja terhadap kinerja karyawan di PT. Bumi Menara Internusa. Pengumpulan data menggunakan data primer yang diperoleh dari kuesioner. Sampel dalam penelitian ini adalah karyawan PT. Bumi Menara Internusa Surabaya yang berjumlah 62 orang. Analisis yang digunakan dalam pengujian hipotesis adalah Statistical package for the social sciences (SPSS) versi 20. Hasil penelitian ini menunjukkan bahwa etos kerja berpengaruh positif tidak signifikan terhadap kinerja karyawan, pelatihan kerja berpengaruh positif dan tidak signifikan terhadap kinerja karyawan, dan disiplin kerja berpengaruh positif tidak signifikan terhadap kinerja karyawan.
\end{abstract}

Kata Kunci: Etos kerja, pelatihan kerja, disiplin kerja dan kinerja karyawan.

\section{PENDAHULUAN}

Situasi global yang semakin berkembang pesat membuat kondisi perusahaan satu dengan perusahaan lainnya harus mampu bersaing dengan baik.persaingan dalam perusahaan perlu di siapkan agar mampu menghasilkan output yang sempurna,. Untuk menghasikan output yang sempurna di dalam perusahaan, di perlukan pelaksanaan kerja yang baik dan sumber daya manusia yang unggul bagi perusahaan. Salah satu solusi yang 
dapat di lakukan untuk menghadapi persaingan yaitu dengan cara meningkatkan daya saing yang baik dalam segi produk atau kualitas produksi pada suatu perusahaan. Perusahaan tidak cukup hanya dengan mempunyai modal besar untuk mencapai tujuannya tetapi harus di bantu oleh karyawan yang unggul.

Kinerja karyawan adalah faktor yang sangat penting dalam menunjang keberhasilan usaha. Kinerja yang tinggi akan sangat mengguntungkan baik bagi pengusaha maupun bagi karyawannya teutama untuk mensejahterahkan. Mangkunegara (2017) melaporkan bahwa kinerja adalah hasil kerja yang secara kualitas dan kuantitas yang telah dicapai oleh seorang karyawan atau pegawai dalam mengemban tugasnya sesuai dengan tanggung jawab yang telah diberikan kepadanya. Kualitas di sini maksudnya adalah dilihat dari segi kebersihan, kehalusan dan ketelitian dalam menjalankan tugas dan pekerjaan nya.Sedangkan, yang dimaksud dengan kuantitas itu dilihat dari banyaknya jumlah pekerjaan yang harus diselesaikan oleh pegawai atau karyawan tersebut. Beberapa faktor yang berpengaruh terhadap kinerja antara lain: etos (ethos), pelatihan (training), dan disiplin (discipline). Dengan menerapkan sistem tersebut diharapkan karyawan dapat melaksanakan tugasnya dengan baik dan bertanggung jawab atas pekerjaan sehingga mampu meningkatkan kinerja karyawan.

Etos kerja yang baik dalam bekerja dapat membantu karyawan untuk memahami bagaimana cara mereka untuk bekerja menjalankan tugasnya. Etos kerja merupakan suatu perasaan, pembicaraan serta tindakan manusia yang bekerja di dalam perusahaan manufacturing, jadi dapat dikatakan bahwa segala sesuatu yang ada di dalam perusahaan, termasuk di dalamnya cara berfikir, bersikap dan bertingkah laku dipengaruhi oleh etos kerja yang ada di perusahaan. Etos kerja yang tinggi akan dijadikan prasyarat yang mutlak, yang harus ditumbuhkan dalam kehidupan ini khususnya penyesuaian karyawan dengan tempat dan rekan kerja (Lawu et al., 2019). Karena hal itu akan membuka pandangan dan sikap menyesuaikan dengan manusianya untuk menilai tinggi terhadap kerja keras dan sungguh-sungguh, sehingga dapat mengikis sikap kerja yang asal-asalan, tidak berorientasi terhadap mutu atau kualitas kerja yang semestinya. Dengan menerapkan sikap dapat menyesuaiakan diri dan kepribadian tersebut maka seorang karyawan dapat mencapai hasil kerja yang optimal dan juga kinerja karyawan tersebut akan meningkat. Hasil ini menunjukkan bahwa suatu etos kerja dapat membantu dalam memunculkan dan juga dapat meningkatkan kinerja setiap karyawan sehingga mereka dapat bekerja secara optimal dan apa yang menjaditujuan perusahaan dapat tercapai. Kemampuan pegawai dalam memahami pentingnya etos kerja yang tinggi seyogyanya harus dimiliki oleh setiap karyawan karena setiap organisasi sangat membutuhkan kerja keras dan komitmen yang tinggi setiap karyawan.

Menurut Sinamo (2011) etos kerja ini merupakan kunci dan fondasi keberhasilan suatu masyarakat atau bangsa diterima secara aklamasi. Selain itu etos kerja merupakan syarat utama bagi semua upaya peningkatan kualitas tenaga kerja atau SDM dalam hal ini kinerja, baik pada level individual, organisasional, maupun sosial. Selanjutnya, etos 
kerja yang dimiliki oleh seseorang atau kelompok masyarakat, akan menjadi sumber motivasi bagi perbuatannya, sehingga dapat meningkatkan kinerja karyawan (Sinamo, 2011).

Faktor yang selanjutnya yang dapat mempengaruhi kinerja karyawan adalah training. Pelatihan kerja merupakan sebuah proses mengajarkan pengetahuan dan keahlian tertentu serta sikap agar karyawan semakin terampil dalam melaksanakan tanggung jawab. Adanya pelatihan kerja mampu meningkatkan pengetahuan serta ketampilan karyawan, sehingga tanggung jawab karyawan tehadap pekerjaannya akan semakin besar (Elnaga dan Imran, 2013). Program pelatihan tidak hanya mengembangkan karyawan tetapi juga membantu organisasi untuk memanfaatkan sumber daya manusiawi mereka sebaik-baiknya demi mendapatkan keunggulan kompetitif. Oleh karena itu, tampaknya wajib oleh perusahaan untuk merencanakan program pelatihan seperti itu bagi karyawannya untuk meningkatkan kemampuan dan kompetensi mereka yang dibutuhkan di tempat kerja (Jie dan Roger, 2005). Peningkatan sistem pelatihan ini juga dapat mempromosikan kinerja yang lebih baik bagi karyawan (Darmawan et al., 2017), dapat mempertajam kemampuan berfikir dan kreativitas karyawan, serta karyawan yang telah diberikan pelatihan juga dapat mengambil keputusan yang lebih baik pada waktunya dan dengan cara yang lebih produktif (David, 2006). Selain itu juga memungkinkan karyawan untuk berurusan dengan pelanggan dengan cara yang efektif dan menanggapi keluhan mereka pada waktu yang tepat (Hollenbeck et al., 2004).

Selain itu, faktor yan lain yang juga dapat mempromosikan kinerja yang lebih baik adalah disiplin kerja. Tumilaar (2015) mengungkapkan bahwa disiplin adalah modal yang dibutuhkan untuk mencapai tujuan yang diinginkan. Jadi keberadaan disiplin kerja yang dibutuhkan dalam suatu perusahaan, karena dalam suasana disiplin suatu organisasi atau lembaga akan dapat melaksanakan program-programnya mencapai tujuan yang ditetapkan. Selain itu, Chien (2004) dalam hasil studinya juga mengungkapkan bahwa disiplin merupakan bagian dari proses mengarahkan atau mengendalikan keinginan kepentingan yang didorong untuk mencapai tujuan yang mengarah pada tindakan yang lebih baik. Sejalan dengan itu, studi yang dilakukan oleh Tumilaar (2015) mengkonfirmasi bahwa pemberian training kepada karyawan ini dapat memberikan dampak yang lebih baik terhadap kinerja mereka pada pekerjaannya di dalam organisasi, yang pada gilirannya mengarah pada pencapaian tujuan organisasi tersebut.

Dengan demikian, pada studi ini bertujuan untuk mengekplorasi tiga faktor penting tersebut yaitu etos kerja, pelatihan, dan disiplin kerja dalam memprediksi kinerja karyawan yang lebih baik seperti yang telah disampaikan oleh para penelitian sebelumnya yang dikaji dalam studi ini. Dimana hasil penelian ini diharapkan dapat memberikan dampak yang lebih baik, baik bagi akademisi sebagai tambahan keilmuan maupun bagi praktisi sebagai acuan untuk pengambilan keputusan dalam menjalankan praktek dalam usaha profesional mereka. 


\title{
TINJAUAN TEORITIS
}

\author{
Etos Kerja
}

Nizam et al. (2016) berpendapat bahwa etos kerja merupakan norma budaya yang mendorong orang untuk bertanggung jawab penuh atas pekerjaan yang mereka lakukan berdasarkan keyakinan bahwa pekerjaan memiliki nilai intrinsik bagi individu. Sapada et al. (2017) etos kerja dijadikan sebagai isyarat kepribadian, temperamen, karakter dan kepercayaan pada sesuatu. Tasmara (2002:56) mengungkapkan bahwa etos kerja ini ditetapkan oleh kebiasaan, pengaruh budaya dan sistem nilai yang diyakini dalam suatu organisasi. Etos kerja juga memiliki banyak elemen seperti yang diungkapkan oleh Wijayanti (2012: 113) seperti yang dikaitkan dengan nilai-nilai psikologis seseorang, menunjukkan pandangan mendarah daging, menunjukkan sikap dan harapan seseorang. Etos kerja juga telah dikaitkan dengan peningkatan kinerja individu yang lebih baik (Nizam et al., 2016) yang bermanfaat untuk organisasi dan kelompok individu di dalamnya (Wood, 2000).

\section{Pelatihan kerja}

Pelatihan kerja merupakan sebuah proses mengajarkan pengetahuan dan kehalian tertentu serta sikap agar karyawan semakin terampil dalam melaksanakan tanggung jawab. Menurut Chiaburu dan Tekleab (2005) pelatihan lebih kepada intervensi yang direncanakan yang bertujuan untuk meningkatkan unsur-unsur kinerja pekerjaan karyawan. Hal ini berkaitan pada peningkatan keterampilan yang diperlukan untuk mencapai tujuan perusahaan/organisasi. Menurut Chen (2004) program pelatihan dapat membantu tenaga kerja untuk mengurangi kecemasan atau frustrasi mereka, yang berasal dari pekerjaan di tempat kerja. Disatu sisi juga, dapat menjadi alat yang efisien dalam meningkatkan kepuasan kerja karyawan dan kinerjanya (Rowden, 2002).

\section{Disiplin kerja}

Definisi dari disiplin sebelumnya telah dipaparkan oleh Sastrohadiwiryo (2003) sebagai sikap hormat, menghormati, mematuhi, dan mematuhi peraturan yang berlaku baik tertulis maupun tidak tertulis dan mampu menjalankan dan tidak menyimpang untuk menerima sanksi jika ia melanggar tugas dan wewenang yang diberikan kepadanya. Selain itu, disiplin juga dianggap sebagai kekuatan yang berkembang dalam tubuh para pekerja itu sendiri yang menyebabkan dia menyesuaikan diri untuk secara sukarela tunduk pada keputusan, peraturan, dan nilai-nilai kerja dan perilaku yang tinggi (Asmiarsih, 2006).Disiplin karyawan akan mempengaruhi efisiensi dan efektivitas pekerjaannya (Sarwani, 2016), serta dapat berpengaruh pada peningkatan performa karyawan secara positif dan signifikan (Isnaini, 2020). 


\section{Kinerja karyawan}

Kinerja Karyawan adalah hasil dari kualitas dan kuantitas dikenakan dicapai oleh seorang karyawan dalam melaksanakan tugasnya sesuai dengan tanggung jawab yang diberikan kepadanya (Keijzers, 2009). Fahmi (2014) kinerja adalah hasil yang dicapai oleh organisasi yang berorientasi pada laba atau non-profit oriented dalam jangka waktu tertentu. Eko (2015) mengatakan bahwa kinerja kerja merupakan nilai prestasi yang merupakan hasil dari pelaksanaan tugas tertentu. Mangkunegara (2013) melaporkan bahwa kinerja individu ditunjukkan melalui kualitas kerja, tanggung Jawab, kerjasama, dan inisiatif karyawan dalam bekerja. Peningkatan kinerja individu ini dapat menyongsong dalam pencapaian kinerja organisasi dan pencapaian atas tujuan yang telah ditetapkan oleh organisasi/perusahaan.

\section{Kerangka Konseptual}

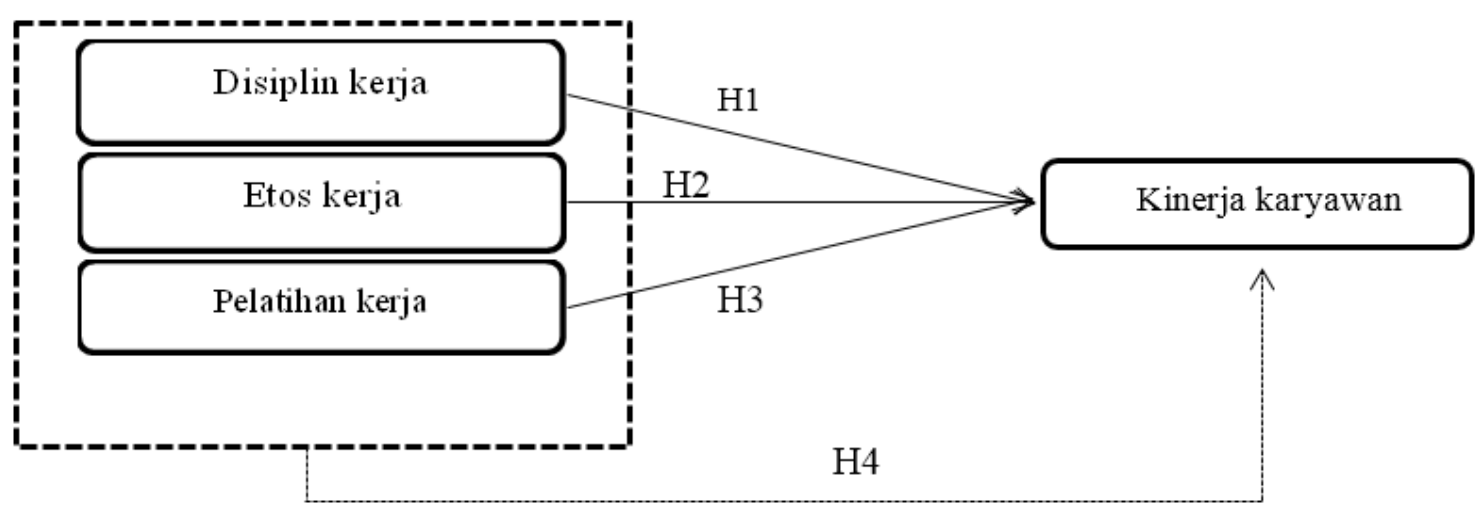

Gambar 1. Kerangka Konseptual

\section{METODOLOGI PENELITIAN}

\section{Jenis dan Pendekatan Penelitian}

Jenis penelitian ini menggunakan penelitian kuantitatif dengan pendekatan asosiatif, penelitian kuantitatif artinya metode penelitian yang digunakan untuk meneliti populasi atau sampel tertentu, pengumpulan data menggunakan instrumen penelitian, analisis data statistik dengan tujuan untuk menggambarkan dan menguji hipotesis yang telah ditetapkan (Sugiyono, 2017). Penelitian ini menggunakan pendekatan asosiatif, metode asosiatif adalah metode statistika yang digunakan untuk menguji hipotesis dan mengetahui hubungan antara satu variabel dengan variabel lainnya, atau bagaimana suatu variabel mempengaruhi variabel lain. 


\section{Lokasi Penelitian}

Penelitian ini dilakukan pada Perusahaan Manufaktur yang bergerak dalam sektor eksport Makanan laut yaitu di PT. BUMI MENARA INTERNUSA yang terletak di Jln. Margomulyo 4E, surabaya..

\section{Populasi, Sampel dan Teknik Pengambilan Sampel}

Populasi menurut Sugiyono (2017: 80)adalah wilayah generalisasi yang terdiri atas objek atau subjekyang mempunyai kualitas dan karakteristik tertentu yang ditetapkan oleh peneliti untuk dipelajari dan kemudian ditarik kesimpulannya. Sampel penelitian menurut Sugiyono (2017:137) adalah bagian dari jumlah dan karakteristik yang dimiliki oleh populasi. Pengukuran sampel merupakan suatu langkah untuk menentukan besarnya sampel yang diambil dalam melaksanakan penelitian. Dalam penelitian ini, penentuan besarnya sampel menggunakan cluster random, dikarenakan pertimbangan operasional tersendat oleh pandemi Covid-19, serta sebagian karyawan banyak yang di rumahkan dan peneliti keterbatasan waktu yang ada.

Terdapat teknik dalam pengambilan sampel untuk melakukan penelitian, menurut Sugiyono (2017:81) menjelaskan bahwa teknik sampel merupakan teknik pengambilan sampel untuk menentukan sampel yang akan digunakan dalam penelitian, terdapat beberapa teknik sampling yang digunakan.Teknik sampling dibagi menjadi dua kelompok yaitu probability sampling dan non probability sampling. Pada penelitian ini, peneliti menggunakan probability sampling. Menurut Sugiyono (2017:82) "probability sampling adalah teknik pengambilan sampel yang memberikan peluang atau kesempatan yang sama bagi setiap unsur atau anggota populasi untuk dipilih menjadi sampel".

\section{Teknik Analisis Data}

Metode analisis data dalam penelitian ini menggunakan analisis regresi linier berganda. Analisis regresi linier berganda digunakan untuk memperoleh gambaran yang menyeluruh mengenai pengaruh antara variabel etos kerja, pelatihan kerja dan disiplin kerja terhadap kinerja karyawan dengan menggunakan program SPSS for Windows versi 21.

\section{HASIL DAN PEMBAHASAN}

Hasil pengujian uji asumsi klasik yang diolah menggunakan software SPSS 21 dapat ditampilkan pada bagian di bawah ini: 


\section{Uji Normalitas}

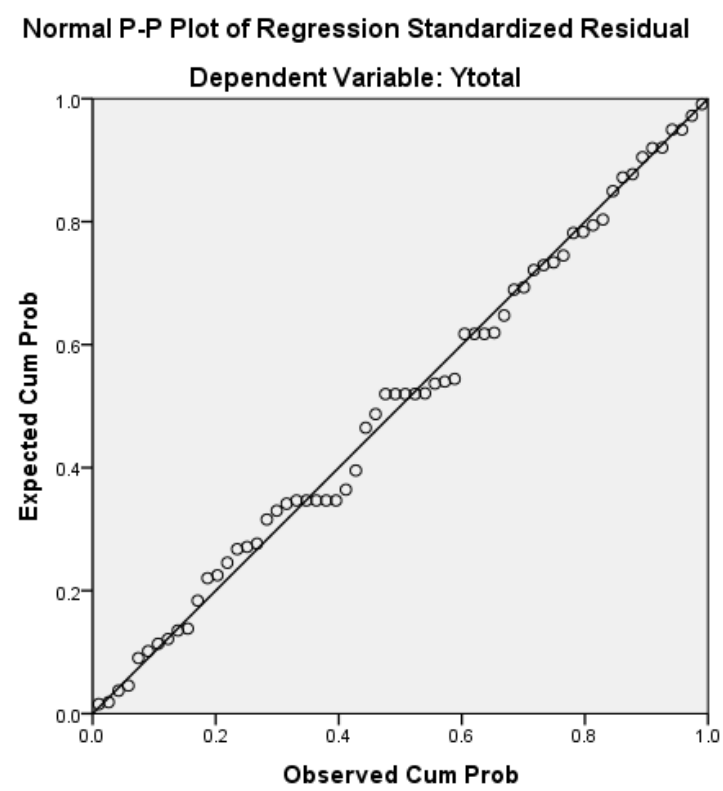

Gambar 2. Normal P-P Plot of Regression Standardized Residual

Disamping menggunakan uji grafik dilengkapi dengan uji statistik, salah satunya dengan menggunakan uji statistik non-parametik Kolmogorof-Smirnov. Jika hasil K-S mempunyai nilai $\mathrm{p} \geq 0,05$, maka dapat dikatakan unstandardized residual normal. Hasil uji tersebut disajikan pada tabel berikut:

Tabel 1. Hasil Uji Normalitas

One-Sample Kolmogorov-Smirnov Test

\begin{tabular}{|ll|l|}
\hline & & $\begin{array}{l}\text { Unstandardiz } \\
\text { ed Residual }\end{array}$ \\
\hline $\mathrm{N}$ & Mean & 62 \\
Normal Parameters & .0000000 \\
& Std. & 1.40572033 \\
& Deviation & \\
Most Extreme & Absolute & .060 \\
Differences $\quad$ Positive & .060 \\
Kolmogorov-Smirnov Z & Negative & -.053 \\
Asymp. Sig. (2-tailed) & .476 \\
\hline
\end{tabular}

a. Test distribution is Normal.

b. Calculated from data.

Sumber: data primer diolah dengan spss (2020)

Berdasarkan tabel di atas terlihat bahwa nilai Kolmogorov-Smirnov Z sebesar 0,476 dengan tingkat signifikan 0,977 berarti hal itu menunjukkan bahwa model regresi terdistribusi normal karena tingkat signifikansinya $>0,05$. 


\section{Uji Multikolinieritas}

Uji multikolinieritas digunakan untuk menguji apakah pada model regresi ditemukan adanya kolerasi antar variabel bebas yaitu etos kerja, pelatihan kerja, dan disiplin kerja. Multikolinieritas dapat diketahui dari nilai Tolerance dan Variance Invlation Factor (VIF). Apabila nilai Tolerance < 0.1 atau Variance Invlation Factor $(\mathrm{VIF})>10$, maka terjadi multikolinieritas. Jika nilai Tolerance $>0.1$ dan nilai Variance Invlation Factor (VIF) < 10, maka tidak terjadi multikolinieritas.

Tabel 2. Hasil Uji Multikolinieritas

Coefficients $^{\text {a }}$

\begin{tabular}{|c|c|c|c|c|c|c|c|c|}
\hline \multirow{2}{*}{\multicolumn{2}{|c|}{ Model }} & \multicolumn{2}{|c|}{$\begin{array}{c}\text { Unstandardized } \\
\text { Coefficients }\end{array}$} & \multirow{2}{*}{$\begin{array}{c}\text { Standardized } \\
\text { Coefficients }\end{array}$} & \multirow[t]{2}{*}{$\mathrm{T}$} & \multirow[t]{2}{*}{ Sig. } & \multicolumn{2}{|c|}{$\begin{array}{c}\text { Collinearity } \\
\text { Statistics }\end{array}$} \\
\hline & & B & Std. Error & & & & Tolerance & VIF \\
\hline \multirow{4}{*}{1} & (Constant) & 28.367 & 2.064 & & 13.747 & .000 & & \\
\hline & X1total & .160 & .141 & .238 & 1.140 & .259 & .376 & 2.659 \\
\hline & X2total & .091 & .111 & .212 & .827 & .412 & .249 & 4.013 \\
\hline & X3total & .065 & .092 & .159 & .707 & .483 & .325 & 3.075 \\
\hline
\end{tabular}

a. Dependent Variable: Ytotal

Berdasarkan Tabel 2 di atas, nilai tolerance semua variabel lebih dari 0,1 dan nilai variance inflation factor (VIF) kurang dari 10. Sehingga dapat diambil kesimpulan bahwa data penelitian ini tidak mengalami multikolinieritas antar variabel bebas.

\section{Uji Heteroskedastisitas}

Uji heteroskedastisitas bertujuan untuk mendeteksi terjadinya nilai relevan yang berbeda dari setiap varian variabel bebas yaitu etos kerja, pelatihan kerja, disiplin kerja. Masalah heteroskedastisitas dalam penelitian ini dideteksi dengan menggunakan scatterplot yaitu dengan memplotkan standardized predictors dengan standardized residual model. Jika tidak ada pola yang jelas, serta titik-titik menyebar di atas dan di bawah angka 0 pada sumbu Y, maka tidak terjadi heteroskedastisitas. Berikut hasil scatterplot yang didapatkan dari output spss. 


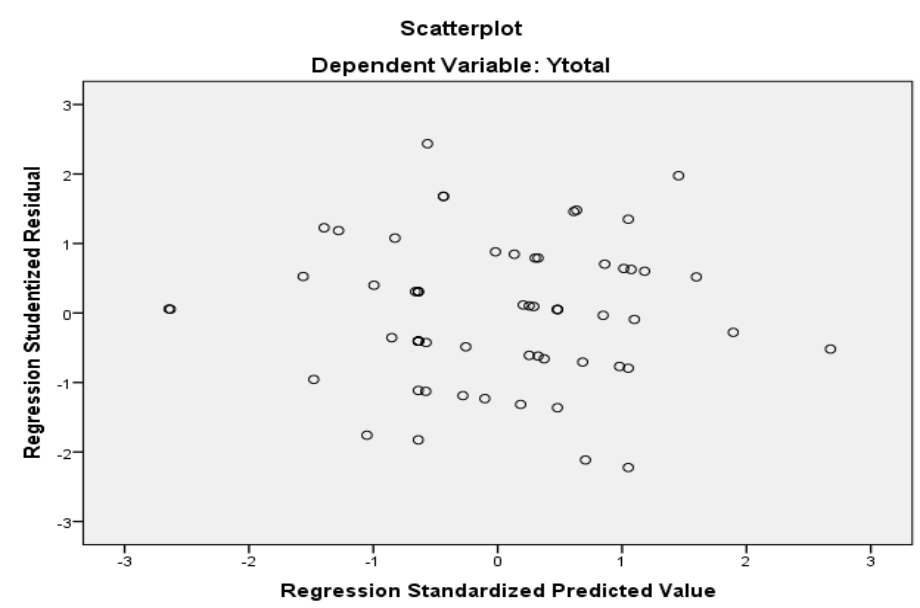

Sumber: data primer diolah dengan spss (2020)

Gambar 3. Uji Heteroskedastisitas

Pada Gambar 3 Hasil uji heteroskedastisitas pada gambar diatas terlihat bahwa scatterplot tidak membentuk suatu pola tertentu serta titik menyebar diatas dan dibawah angka 0 pada sumbu Y maka tidak terjadi heteroskedastisitas.

\section{Uji Hipotesis}

\section{Analisis Regresi Linear Berganda}

Untuk mengetahui pengaruh variabel etos $\left(\mathrm{X}_{1}\right)$, pelatihan $\left(\mathrm{X}_{2}\right)$ dan disiplin kerja $\left(\mathrm{X}_{3}\right)$ terhadap kinerja $(\mathrm{Y})$, maka digunakan teknik analisis regresi linier berganda. Regresi linier berganda dipergunakan untuk sebuah variabel terikat dan lebih dari satu buah variabel bebas. Perhitungan data dilakukan dengan menggunakan Statistic Program of Social Science (SPSS) For Windows versi 20. Hasil uji analisis regresi linier berganda dapat dilihat pada Tabel 3.

\section{Coefficients $^{\text {a }}$}

Tabel 3. Regresi Linear Berganda

\begin{tabular}{|c|c|c|c|c|c|c|}
\hline \multirow{2}{*}{\multicolumn{2}{|c|}{ Model }} & \multicolumn{2}{|c|}{$\begin{array}{l}\text { Unstandardized } \\
\text { Coefficients }\end{array}$} & $\begin{array}{l}\text { Standardized } \\
\text { Coefficients }\end{array}$ & \multirow[t]{2}{*}{$\mathrm{T}$} & \multirow[t]{2}{*}{ Sig. } \\
\hline & & B & Std. Error & Beta & & \\
\hline \multirow{4}{*}{1} & (Constant) & 28.367 & 2.064 & & 13.747 & .000 \\
\hline & X1total & .160 & .141 & .238 & 1.140 & .259 \\
\hline & X2total & .091 & .111 & .212 & .827 & .412 \\
\hline & X3total & .065 & .092 & .159 & .707 & .483 \\
\hline
\end{tabular}

a. Dependent Variable: Ytotal

Dari Tabel 3 diatas, dapat digunakan untuk menyusun model persamaan linier berganda sebagai berikut :

$$
\mathrm{Y}=28.367+0,160 \mathrm{X} 1+0,091 \mathrm{X} 2+0,065 \mathrm{X} 3
$$


Dari persamaan regresi tersebut dapat diketahui bahwa :

a) Nilai konstanta sebesar 28,367 menyatakan bahwa jika etos kerja, pelatihan kerja dan disiplin kerja dengan nol, maka kinerja karyawan (Y) adalah sebesar 28,367.

b) Nilai koefisien regresi variabel etos kerja $\left(\mathrm{X}_{1}\right)$ adalah sebesar 0,160 artinya apabila etos kerja $\left(\mathrm{X}_{1}\right)$ berubah satu satuan, maka variabel kinerja karyawan (Y) akan berubah 0,160 satuan dengan anggapan variabel lainnya tetap.

c) Nilai koefisien regresi variabel pelatihan kerja $\left(\mathrm{X}_{2}\right)$ adalah sebesar 0,091 artinya apabila pelatihan kerja $\left(\mathrm{X}_{2}\right)$ berubah satu satuan, maka variabel kinerja karyawan $(\mathrm{Y})$ akan berubah 0,091 satuan dengan anggapan variabel lainnya tetap.

d) Nilai koefisien regresi variabel disiplin $\operatorname{kerja}\left(\mathrm{X}_{3}\right)$ adalah sebesar 0,065 artinya apabila disiplin kerja $\left(\mathrm{X}_{3}\right)$ berubah satu satuan, maka variabel kinerja guru $(\mathrm{Y})$ akan berubah 0,065 satuan dengan anggapan variabel lainnya tetap.

\section{Uji Koefisien Determinasi}

Tabel 4. Uji Koefisien Determinasi

Model Summaryb

\begin{tabular}{|l|r|r|r|r|r|}
\hline Model & R & R Square & $\begin{array}{c}\text { Adjusted R } \\
\text { Square }\end{array}$ & $\begin{array}{c}\text { Std. Error of the } \\
\text { Estimate }\end{array}$ & Durbin-Watson \\
\hline 1 & $.741^{\mathrm{a}}$ & .549 & .505 & 5.407 & 1.396 \\
\hline
\end{tabular}

a. Predictors: (Constant), X3total, X1total, X2total

b. Dependent Variable: Ytotal

Sumber: data primer diolah dengan spss (2020)

Pada Tabel 4 diatas, hasil analisis determinasi diperoleh angka R2 (R Square) sebesar 0,549 atau $54,9 \%$. Hal ini menunjukkan bahwa persentase pengaruh variabel independen yaitu etos kerja $\left(\mathrm{X}_{1}\right)$, pelatihan kerja $\left(\mathrm{X}_{2}\right)$ dan disiplin kerja $\left(\mathrm{X}_{3}\right)$ terhadap variabel dependen kinerja sebesar 54,9\% atau dapat dikatakan bahwa 54,9\% variabel kinerja $(\mathrm{Y})$ dipengaruhi oleh variabel etos kerja $\left(\mathrm{X}_{1}\right)$, pelatihan kerja $\left(\mathrm{X}_{2}\right)$ dan disiplin kerja $\left(\mathrm{X}_{3}\right)$. Sedangkan sisanya sebesar $45,1 \%$ dipengaruhi oleh variabel lain yang tidak diteliti dan besarnya pengaruh lain ini sering disebut sebagai error (e).

\section{Uji t (Parsial)}

Tabel 5. Uji hasil $\mathrm{t}$ (parsial)

\section{Coefficients $^{\mathrm{a}}$}

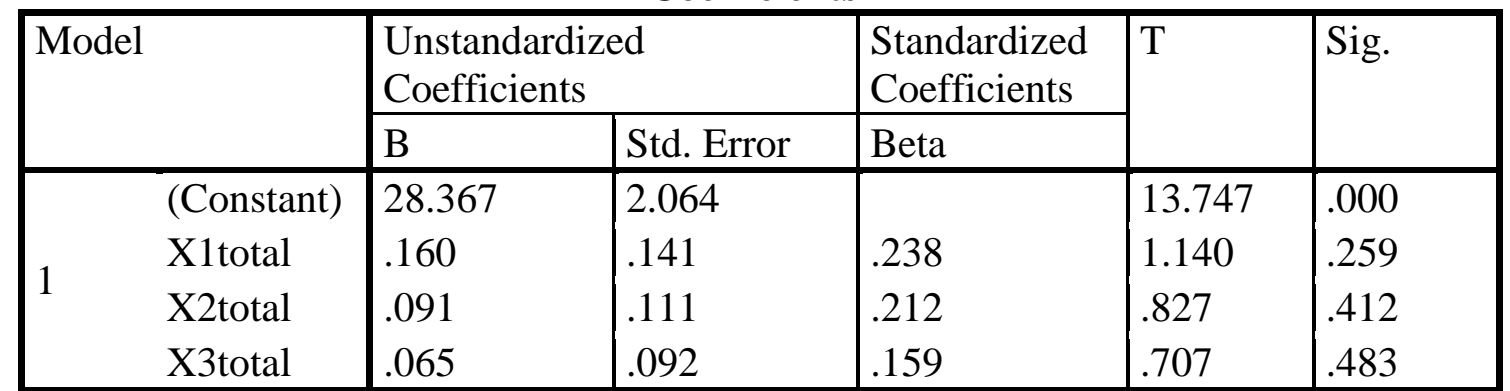

a. Dependent Variable: Ytotal 
Berdasarkan tabel di atas dapat di tarik kesimpulan sebagai berikut :

1. Nilai thitung variabel etos kerja (X1) sebesar 1,140 berada pada tingkat probanilitas signifikan di atas 0,05 yaitu 0,259. Jadi berdasarkan tingkat probabilitas signifikansinya, dapat di simpulkan bahwa variabel etos kerja (X1) tidak memiliki pengaruh signifikan terhadap kinerja karyawan (Y).

2. Nilai thitung variabel pelatihan kerja (X2) sebesar 0,827 berada pada tingkat probabilitas signifikan di atas 0,05 yaitu 0,412. Jadi berdasarkan tingkat probabilitas signifikansinya, dapat di simpulkan bahwa variabel pelatihan kerja (X2) tidak memiliki pengaruh signifikan terhadap kinerja karyawan (Y).

3. Nilai thitung variabel disiplin kerja (X3) sebesar 0,707 berada pada tingkat probanilitas signifikan di atas 0,05 yaitu 0,483. Jadi berdasarkan tingkat probabilitas signifikansinya, dapat di simpulkan bahwa variabel pelatihan kerja (X3) tidak memiliki pengaruh signifikan terhadap kinerja karyawan (Y).

\section{Uji F (Simultan)}

Tabel 6. Uji hasil F (simultan)

ANOVA ${ }^{\mathrm{a}}$

\begin{tabular}{|ll|ll|l|l|l|l|}
\hline \multicolumn{2}{|l|}{ Model } & $\begin{array}{l}\text { Sum } \\
\text { Squares }\end{array}$ & of & Df & Mean Square & F & Sig. \\
\hline \multirow{2}{*}{1} & Regression & 6.300 & 3 & 2.100 & 3.134 & $.395^{\mathrm{b}}$ \\
& Residual & 120.539 & 58 & 2.078 & & \\
& Total & 126.839 & 61 & & & \\
\hline
\end{tabular}

a. Dependent Variable: Ytotal

b. Predictors: (Constant), X3total, X1total, X2total

Sumber: data primer diolah dengan spss (2020)

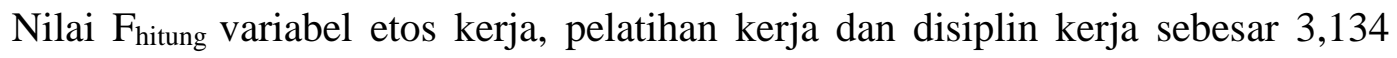
berada pada tingkat probabilitas signifikan di atas 0,05 yaitu 0,395. Jadi berdasarkan tingkat probabilitas signifikansinya, dapat di simpulkan bahwa variabel etos kerja (X1), pelatihan kerja (X2) dan disiplin kerja (X3) tidak memiliki pengaruh signifikan terhadap kinerja karyawan (Y).

\section{PEMBAHASAN}

Penelitian ini terdiri dari 62 responden yang bekerja di PT. Bumi Menara Internusa. 62 responden tersebut kemudian dikelompokkan berdasarkan jenis kelamin, usia,domisili, bagian, pendidikan terakhir, dan lama bekerja. Berdasarkan jenis kelaminnya, diketahui bahwa responden dalam penelitian ini kebanyakan perempuan dan laki laki hanya $32.3 \%$. Kemudian berdasarkan usianya, diketahui bahwa sebagian besar responden dalam penelitian ini berada dalam rentang usia $>18-25$ tahun. Lalu berdasarkan pendidikan terakhirnya, diketahui bahwa sebagian besar responden dalam penelitian ini mempunyai pendidikan terakhir di jenjang SMA/sederajat. Sedangkan berdasarkan masa kerjanya, diketahui bahwa sebagian besar responden dalam penelitian ini telah bekerja 
dalam rentang waktu > 1tahun -5 tahun. Berikut ini adalah pembahasan dari hasil penelitian dan pengolahan data yang telah dilakukan :

\section{Pengaruh Etos Terhadap Kinerja}

Hasil analisa menunjukkan bahwa variabel etos berpengaruh positif dan tidak signifikan terhadap kinerja karyawan di PT. Bumi Menara Internusa, Surabaya. Penerapan etos kerja di perusahaan penelitian sudah berjalan baik dengan indikator pernyataan " tidak mengeluh dan komitmen diri untuk mencapai target dengan sungguhsungguh" sebagai faktor terbesar dengan presentase 61,3\%. Hasil uji t ( Parsial ) antara variabel etos terhadap kinerja dengan nilai t sebesar 1,140, nilai koefisien regresi sebesar 0,238 dan nilai signifikansinya sebesar 0,259 tidak signifikan $>0,05$. namun tinggi rendahnya kinerja karyawan tidak hanya dipengaruhi oleh variabel etos. Maka variabel etos berpengaruh secara parsial terhadap kinerja karyawan.

\section{Pengaruh Pelatihan Terhadap Kinerja}

Pelatihan kerja merupakan proses mengajarkan karyawan baru atau yang ada sekarang, keterampilan dasar yang mereka butuhkan untuk menjalankan pekerjaan mereka. Dengan adanya keterampilan yang cukup maka kinerja yang dihasilkan oleh karyawan akan lebih baik sehingga akan berdampak positif bagi perkembangan dan kemajuan perusahaan tersebut. Hasil analisa menunjukkan bahwa variabel pelatihan berpengaruh positif dan tidak signifikan terhadap kinerja karyawan. Pelatihan dengan indikator pernyataan "perduli terhadap perawatan sarana dan prasarana kerja merupakan bagian dari pekerjaan" dengan nilai presentase 59.7\% . Hasil uji t (Parsial) antara variabel pelatihan terhadap variabel kinerja karyawan dengan nilai thitung sebesar 0.212 , nilai koefisien regresi sebesar 0,827 dan nilai signifikansinya sebesar 0,412 tidak signifikan $>0,05$. Maka variabel pelatihan tidak berpengaruh positif dan tidak signifikan terhadap kinerja. Hal ini menunjukkan bahwa apabila pelatihan mempunyai peranan yang sangat dalam meningkatkan kinerja karyawan, karena dengan pelatihan tersebut karyawan bisa bekerja dengan lebih baik sesuai dengan tanggung jawab dan bidangnya masing-masing.

\section{Pengaruh Disiplin Terhadap Kinerja}

Disiplin merupakan salah satu faktor yang sangat penting dalam mencapai tujuan organisasi atau perusahaan.Disiplin kerja mempunyai pengaruh positif terhadap kinerja karyawan. Dengan menerapkan disiplin kerja dengan baik maka kinerja karyawan akan meningkat.

Hasil analisa menunjukkan bahwa variabel disiplin tidak berpengaruh positif dan tidak signifikan terhadap kinerja karyawaan di perusahaan PT. Bumi Menara Internusa, Surabaya. Penerapan disiplin di perusahaan penelitian sudah berjalan baik dengan indikator "selalu hadir tepat waktu" sebagai faktor terbesar dengan persentase 6,1\%, Hasil uji t (Parsial) antara variabel motivasi terhadap kinerja dengan nilai t sebesar 0.159, nilai 
koefisien regresi sebesar 0,707 dan nilai signifikansinya sebesar 0,483 tidak signifikan $>0,05$.

\section{Pengaruh etos, Pelatihan, dan Disiplin secara simultan Terhadap Kinerja}

Hasil analisis menunjukkan bahwa etos $\left(\mathrm{X}_{1}\right)$, pelatihan $\left(\mathrm{X}_{2}\right)$ dan disiplin $\left(\mathrm{X}_{3}\right)$ secara simultan berpengaruh terhadap kinerja karyawan (Y). Berdasarkan hasil pengujian hipotesis secara simultan (uji F) yang sudah dilakukan, diperoleh hasil bahwa $F_{\text {hitung }}$ sebesar $3.134>\mathrm{F}_{\text {tabel }}$ sebesar 0,250 sehingga dapat diartikan bahwa secara simultan variabel etos, pelatihan, dan disiplin berpengaruh signifikan terhadap kinerja karyawan.

\section{KESIMPULAN}

Berdasarkan data dan hasil analisa yang sudah diperoleh, dan pembahasan serta pengujian yang telah dilakukan sebelumnya, maka dapat diperoleh kesimpulan secara berikut :

1. Secara parsial etos kerja berpengaruh tidak signifikan terhadap kinerja karyawan di PT. Bumi Menara Internusa.

2. Secara parsial pelatihan kerja berpengaruh tidak signifikan terhadap kinerja karyawan di PT. Bumi Menara Internusa.

3. Secara parsial disiplin berpengaruh tidak signifikan terhadap kinerja karyawan PT. Bumi Menara Internusa.

4. secara simultan etos kerja (X1), pelatihan (X2), dan disiplin (X3) berpengaruh tidak signifikan terhadap kinerja (Y) pada perusahaan PT. Bumi Menara Internusa.

\section{SARAN}

1. Di harapkan perusahaan agar untuk mereview kembali peraturan-peraturan dan kebijakan - kebijakan yang ada, terutama peraturan kedisiplinan karyawan.

2. Pihak perusahaan diharapkan lebih memberitahukan tentang peraturan yang berlaku di lingkungan kerja dan memberikan sanksi yang sesuai untuk lebih meningkatkan kedisiplinan kerja bagi semua karyawan

3. Pihak perusahaan di harapkan untuk mengevaluasi pelatihan-pelatihan kembali yang ada di perusahaan, supaya dapat di sesuaikan dengan kebutuhan karyawan.

4. Pihak perusahaan sebaiknya juga memberikan edukasi agar karyawan dapat mengembangkan keterampilan dan kemampuan para karyawan secara terusmenerus. 


\section{DAFTAR PUSTAKA}

Asmiarsih, T. (2006). Pengaruh Pengawasan Terhadap Disiplin Kerja Pegawai Kantor Badan Kepegawaian Daerah Brebes. Semarang: Fakultas IlmuSosial Universitas.

Chen. (2004). IPO Under pricing In China: New Evidence From The Primary And Secondary Markets. Emerging Market Review, 9(1), 1-16.

Chiaburu, D.S. and Tekleab, A.G. (2005). Individual and contextual influences on multiple Dimensions of training effectiveness. Journal of European Industrial Training, 29(8), 604-26

Chien, M. H. (2004). A Study to Improve Organizational Performance: A View from Strategic Human Resource Management. The Journal of American Academy and Business, 289-291.

Darmawan, Y., Supartha, W. G., \& Rahyuda, A. G. (2017). Pengaruh Pelatihan Terhadap Motivasi Kerja dan Kinerja di Prama Sanur Beach-Bali. E-jurnal Ekonomi dan Bisnis Universitas Udayana, 6(3), 17-32.

David, F. R. (2006). Manajemen Strategis : Konsep. Edisi Sepuluh. Jakarta: Salemba Empat

Eko, W.P. (2015). Manajemen Pengembangan Sumber Daya Manusia.Yogyakarta: Pustaka Pelajar.

Elnaga, A dan Imran, A. (2013). The Effect of Training on Employee Performance. European Journal of Business and Management, 5(4), 137-147

Fahmi, I. (2014). Manajemen Strategis Teori dan Aplikasi, Bandung: Alfabeta.

Hollenbeck, J. R., Derue, D.S. \& Guzzo, R. (2004), Bridging the gap between I/O research and HR practice: improving team composition, team training and team task design. Human Resource Management Journal, Vol.4., 353-366

Isnaini., Hamsani., \& Andriyansah. (2020). the effect of work discipline and work motivation towards the performances of LPP RRI employees. Jurnal Wawasan Manajemen, 8(1), 45-56

Jie, S \& Roger, D. (2005). Training and Management Development In Chinese Multinational Enterprise, Employee Relations, Vol. 28 Iss: 4 pp. 342 - 362.

Keijzer, C., Buitelaar, D. (2009). A Comparison of postoperative throat and neck complaints anter the use of I-gel and the La Premiere Disposible Laryngel Mask: a double-blinded, randomized, controlled trial. Anaesh Analg: 109(4);1092-4.

Lawu, S. H., Suhaila, A., dan Lestiowati, R. (2019). Pengaruh Etos Kerja Terhadap Kinerja Karyawan Pada PT Pos Indonesia Cabang Pemuda Jakarta Timur. Managerial - Jurnal Penelitian Ilmu Manajemen, 2(1), 51-60.

Mangkunegara, A. A. A. P. (2016). Manajemen Sumber Daya Manusia Perusahaan. Bandung : PT. Remaja Rosdakarya. 
IMKA Implementasi Manajemen \& Kewirausahaan - Oktober, Vol. 1, No. 2, 126-140, 2021

Mangkunegara, A.P. (2017). Manajemen Sumber Daya Manusia. Cetakan ke 14. Bandung: PT Remaja Rosdakarya.

Nizam, S., Ruzainy, M.N., Sarah, S., Syafna, S. (2016), The relationship between work ethics and job performance. In: Paper Presented at the International Conference on Business and Economics. Poland: University of Szczecin.

Rowden, R. W. (2002). The relationship between workplace learning and job satisfaction in U.S. small to midsize businesses. Human Resource Development Quarterly, 13(4), 407-425.

Sapada, A. F. A., Modding, H. B., Gani, A., \& Nujum, S. (2017). The effect of organizational culture and work ethics on job satisfaction and employees performance. The International Journal of Engineering and Science (IJES), 6(12), 28-36.

Sarwani. (2016). The effect of work discipline and work environment on the performance of employees. Sinergi, 6(2), 53-67.

Sastrohadiwiryo, B. S. (2003). Manajemen Tenaga Kerja Indonesia Pendekatan Administratif dan Operasional. Jakarta: Bumi Aksara.

Sinamo, J. (2011). 8 Etos Kerja Profesional. Jakarta: Institut Dharma Mahardika

Sugiyono. (2017). Metode Penelitian Kuantitatif, Kualitatif, dan R\&D. Bandung : Alfabeta, CV.

Tasmara, Toto. (2002). Cultivating Islamic Work Ethics, Jakarta: Gema Insani Press.

Tumilaar, B. R. (2015). The Effect Of Discipline, Leadership, And Motivation On Employee Performance at BPJS Ketenagakerjaan Sulut. Jurnal EMBA, 3(2), Hal. 787-797

Wood, G. (2000). A cross cultural comparison of the content of codes of ethics: USA, Canada and Australia. Journal of Business Ethics, 25, 287-298. 